\title{
Guidelines for documenting and reporting tree allometric equations
}

\author{
Miguel Cifuentes Jara • Matieu Henry • Maxime Réjou-Méchain • Craig Wayson • \\ Mauricio Zapata-Cuartas • Daniel Piotto • Federico Alice Guier • \\ Héctor Castañeda Lombis • Edwin Castellanos López • Ruby Cuenca Lara • \\ Kelvin Cueva Rojas • Jhon Del Águila Pasquel • Álvaro Duque Montoya • \\ Javier Fernández Vega • Abner Jiménez Galo • Omar R. López • \\ Lars Gunnar Marklund • José María Michel Fuentes • Fabián Milla • \\ José de Jesús Návar Chaidez • Edgar Ortiz Malavassi • Johnny Pérez • \\ Carla Ramírez Zea • Luis Rangel García • Rafael Rubilar Pons • \\ Laurent Saint-André • Carlos Sanquetta • Charles Scott • James Westfall
}

Received: 16 April 2014 / Accepted: 11 July 2014 /Published online: 7 August 2014

(C) INRA and Springer-Verlag France 2014. This article is published with open access at Springerlink.com

\section{Introduction}

Given the pressing need to quantify carbon fluxes associated with terrestrial vegetation dynamics, an increasing number of researchers have sought to improve estimates of tree volume, biomass, and carbon stocks. Tree allometric equations are critical tools for such purpose and have the potential to

Handling Editor: Erwin Dreyer

Contribution of co-authors Miguel Cifuentes Jara and Matieu Henry organized and facilitated the discussions which produced the ideas and opinions contained in this paper. They also led the writing and editing of the document. Additional authors provided edits and inputs to the final manuscript.

\section{Cifuentes Jara $(\triangle)$}

Climate Change and Watersheds Program, CATIE, CATIE 7170,

Cartago, Turrialba 30501, Costa Rica

e-mail: mcifuentes@catie.ac.cr

\section{Henry}

UN-REDD Programme, Food and Agriculture Organization of the United Nations (FAO), Viale delle Terme di Caracalla, 00153 Rome, Italy

\section{Réjou-Méchain}

Laboratoire Evolution et Diversite Biologique, UMR 5174 CNRS,

Université Paul Sabatier, 31062 Toulouse, France

C. Wayson

USDA Forest Service, International Programs - SilvaCarbon, Lima, Peru

\section{Zapata-Cuartas}

Smurfit Kappa Cartón de Colombia, Km 15 Carretera Cali, Yumbo, Colombia improve our understanding about carbon sequestration in woody vegetation, to support the implementation of policies and mechanisms designed to mitigate climate change (e.g. CDM and REDD+; Agrawal et al. 2011), to calculate costs and benefits associated with forest carbon projects, and to improve bioenergy systems and sustainable forest management (Henry et al. 2013).
D. Piotto

Universidade Federal do Sul da Bahia, BR 415, km 39, Ferradas, Itabuna-BA 45613-204, Brazil

\section{F. Alice Guier}

Universidad Nacional de Costa Rica, Campus Omar Dengo, Heredia, Costa Rica

H. Castañeda Lombis · A. Jiménez Galo REDD/CCAD-GIZ, Boulevard Orden de Malta, San Salvador, El Salvador

E. Castellanos López

Universidad del Valle de Guatemala, 18 AV. 11-95 Zona 15, Guatemala City, Guatemala

R. Cuenca Lara $\cdot$ L. Rangel García Comisión Nacional Forestal (CONAFOR), Periférico Poniente 5360 Col. San Juan de Ocotan Zapopan, Jalisco, Mexico 
Many methods, ranging from the most generic (i.e. IPCC Tier 1) to site- and species-specific (i.e. Tiers 2 and 3) are available for estimating tree biomass. The most widely used approach is the use of generic equations based on trees harvested in several sites (Brown 1997; Jenkins et al. 2003; Chave et al. 2005; Chave et al. 2014; Chojnacky et al. 2014). However, such generic equations may lead to systematic errors of up to $400 \%$ at the site level (Alvarez et al. 2012; Ngomanda et al. 2014; Chave et al. 2014). Well-implemented, locally developed models may be a better alternative and are expected to provide less uncertainty than generic equations (Chave et al. 2014). However, the lack of proper documentation describing the methods used to develop equations is a major obstacle to choosing the most appropriate model.

Until recently, there was no harmonized global repository of allometric equations that could aid in choosing the tree biomass or volume model most adapted to a given study site. The GlobAllomeTree platform (http://www.globallometree.org/; Henry et al. 2013) is a first step towards this goal but also has raised the issue of the lack of consistency in how allometric equations and their associated metadata are reported. A large number of the publications reviewed for inclusion into GlobAllomeTree did not comply with basic IPCC "good practice" guidelines (IPCC 2003) in terms of completeness,

\section{K. Cueva Rojas}

FAO-Ecuador, Edificio Ministerio de Agricultura, Ganadería, Acuacultura y Pesca, Av. Eloy Alfaro y Amazonas, Quito, Ecuador

J. Del Águila Pasquel

Instituto de Investigaciones de la Amazonia Peruana (IIAP), Av. José

Abelardo Quiñones km 2.5, Iquitos, Peru

\author{
Á. Duque Montoya \\ Universidad Nacional de Colombia, Calle 59A \#63-20, Medellin, \\ Colombia \\ J. Fernández Vega \\ Fondo Nacional de Financiamiento Forestal (FONAFIFO), Oficinas
}

Centrales, Moravia, San José, Costa Rica

\section{O. R. López}

INDICASAT-AIP, Edificio 219, Clayton, Ciudad del Saber, Panama

City, Panama

O. R. López

Smithsonian Tropical Research Institute, Apartado Postal

0843-03092, Balboa, Ancón Panama City, Panama

L. G. Marklund

FAO-SLM, Cuidad del Saber, ED 238, Panama City, Panama

J. M. Michel Fuentes

FAO-México, Periférico Poniente 5360 Col. San Juan de Ocotan

Zapopan, Jalisco, Mexico

F. Milla

Universidad de Concepción, Campus Los Ángeles, J.A. Coloma

0201, Los Ángeles, Chile documentation, transparency, or comparability. Although a few authors have proposed general guidelines to describe and evaluate allometric equations (Baldasso et al. 2012; Bombelli et al. 2009; IPCC 2003, 2006; Jenkins et al. 2003; Picard et al. 2012; Ponce-Hernandez 2004; Pretzsch et al. 2002), no document gives practical recommendations on the necessary information that should be provided with published allometric models. Authors are left to their own initiative to decide the breadth and depth of information they publish about the allometric equations they develop, leading to the abovementioned inconsistencies between studies. For instance, many published equations lack basic descriptions of the study location, sampling design, the statistics associated with the equation, or even the allometric model construction. This missing information limits the harmonization and use of allometric equations in a transparent and comparable way and the estimation of associated uncertainties and, ultimately, prevents scientific progress towards sustainable forestry practices.

We address that need by providing standard guidelines for publishing allometric equations worldwide. These recommendations are the result of expert discussions held during the "Regional Technical Workshop on Tree Volume and Biomass Allometric Equations in South and Central America" in Costa Rica, on May 21-24, 2014. The workshop brought together

J. d. J. Návar Chaidez

CIIDIR-IPN Unidad Durango, Sigma \# 119 Fracc. 20 de Noviembre 11, 34220 Durango, DGO, Mexico

E. Ortiz Malavassi

Instituto Tecnológico de Costa Rica, Apartado 159-7050 Cartago, Costa Rica

J. Pérez

Escuela Nacional de Ciencias Forestales (ESNACIFOR), Colonia las Américas, Siguatepeque, Comayagua, Honduras

C. Ramírez Zea

FAO-PERÚ, Manuel Oleachea 414, Miraflores, Lima, Peru

R. Rubilar Pons

Universidad de Concepción, Víctor Lamas 1290, Concepción, VIII Región del Biobío, Chile

L. Saint-André

INRA, UR1138, Unité Biogéochimie des Ecosystèmes Forestiers (BEF), Centre INRA de Nancy, 54280 Champenoux, France

L. Saint-André

CIRAD, UMR ECO\&SOLS, 34000 Montpellier, France

C. Sanquetta

Federal University of Paraná, Ave. Lothario Meissener 900 Jardin Botánico, Rio de Janeiro, Brazil

C. Scott $\cdot$ J. Westfall

US Forest Service, 11 Campus Blvd., Newtown Square, PA, USA 
30 scientists from throughout Latin America, the USA, and Europe to discuss the state of the art on allometric equations, identify knowledge gaps, and offer potential ways forward. We expect the widespread adoption of these guidelines will lead to a more complete and harmonized reporting of information on tree allometric equations worldwide, which will increase their value and robustness for predicting biomass and carbon stocks.

\section{Recommended guidelines for documenting allometric equations}

The following recommendations should apply to all situations and circumstances where an allometric equation is published in the scientific or technical literature. We focus on six areas: definitions and concepts, description of the target population and environmental conditions where the study was carried out, sampling details and scope of the study, methods for data analysis and calculations, model fitting and uncertainty, and metadata (Table 1). All this information should be included within the main document or in its associated appendices and may be organized in tables when dealing with multiple equations.

\subsection{Definitions and concepts}

Authors should describe the variables and units used in field measurements or in data processing and of the output estimates from allometric equations. Units need to be stated using the International System of Units (SI). Clearly defined variables aid in understanding which tree components were considered in developing the allometric equations. For example, it is not always obvious if a basic variable such as "tree height" refers to total tree height or to commercial tree height (e.g. Feldpausch et al. 2010 or Ribeiro et al. 2011). Information about the height where the diameter measurement was taken is needed. For example, if trees were buttressed or were irregular at the standard point of measurement $(1.3 \mathrm{~m})$, how were diameters measured? Similar details on volume and tree components included in the model need to be clearly stated.

\subsection{Description of the target population and environmental conditions}

A proper environmental description of the sites where equations were constructed allows researchers to determine whether allometric models constructed elsewhere would be valid in their study areas. The location (latitude, longitude, and altitude data) and environmental conditions of all sampling areas are mandatory. If coordinates are projected, reporting the projection system is needed.

Information on climate variables should include at least mean annual temperature, mean annual precipitation, and the length of the dry season ( $<100 \mathrm{~mm} / \mathrm{month})$, if any. Including additional variables such as seasonality, water deficit, and maximum and minimum values is advisable. It is recommended to also provide information from the country's specific or an international preferred ecological zone classification system such as FAO (2001), Olson et al. (2001), Holdridge (1967), Udvardy (1975), or Bailey (1989).

Known or approximate stand age should be indicated, together with a description of the forest community (dominant species, tree abundance or stand density, basal area, disturbance regime, and phenology) and management system. Whenever possible, it is also recommended to provide information on soils (e.g. texture and depth) and landscape characteristics (elevation, slope, aspect) of the sampling sites. It would also be advisable to include some mention of the geographic representativeness of any sample set.

\subsection{Sampling and scope of the study}

It is essential that much thought and precise documentation exist for the sample design and actual sampling needed to construct robust allometric equations. This includes information on the number of trees considered, the range of diameter, the tree components measured (e.g. were the belowground components measured?), the area investigated (e.g. trees were harvested in a single plot or in several randomly located within a landscape), and whether trees were chosen randomly, based on diameter classes, vertical stratification, or floristic composition. Such information helps potential users to gauge the robustness of models and determine the limits of their application.

We recommend that the tree partitioning proposed by Henry et al. (2011) be adopted as a minimum standard for partitioning tree components during biomass harvests and data processing: stump, trunk, bark, small roots $(D<5 \mathrm{~mm})$, medium roots $(5<D<10 \mathrm{~mm})$, big roots $(D>10 \mathrm{~mm})$, thin branches $(D<7 \mathrm{~cm})$, large branches $(D>7 \mathrm{~cm})$, dead branches, leaves, and fruits. With small roots, it may be necessary to choose a cutoff diameter and clearly state that the biomass equation only accounts for roots larger than that, as other more detailed methods are available to account for this highly dynamic component (Vogt et al. 1998).

Since common names vary considerably among locations, and taxonomy is being updated constantly, it is desirable to have both lists made available to users. Efforts should be made to have taxonomists identify the harvested tree species in the field and to collect voucher specimens and deposit them in an institutional herbarium.

\subsection{Methods used for data and laboratory analyses}

Reporting measurement methods, tools, and calculation procedures also helps to evaluate the model robustness and allows to replicate measures and model construction with expanded 
Table 1 Checklist of recommended guidelines for documenting allometric equations in scientific or technical publications

\begin{tabular}{|c|c|c|}
\hline Guideline category & \multicolumn{2}{|c|}{ Information to include } \\
\hline \multirow[t]{6}{*}{ Definitions and concepts } & \multicolumn{2}{|c|}{ Mandatory } \\
\hline & $\square$ & Tree components measured (e.g. bole, crown, roots) \\
\hline & $\square$ & Type of height measurements (total, commercial) \\
\hline & $\square$ & Type of diameter measurements (point of measurement) \\
\hline & $\square$ & Units of measures \\
\hline & $\square$ & Definitions of variables used \\
\hline \multirow{13}{*}{$\begin{array}{l}\text { Target population and } \\
\quad \text { environmental conditions }\end{array}$} & \multicolumn{2}{|c|}{ Mandatory } \\
\hline & $\square$ & Geographic coordinates (latitude and longitude) and projection system \\
\hline & $\square$ & Elevation (in $\mathrm{m}$ above sea level) \\
\hline & $\square$ & $\begin{array}{l}\text { Climate variables: mean annual temperature }\left({ }^{\circ} \mathrm{C}\right) \text {, mean annual precipitation } \\
(\mathrm{mm} / \text { year), length of dry season (in month with rainfall }<100 \mathrm{~mm})\end{array}$ \\
\hline & $\square$ & Estimated age or successional status \\
\hline & \multicolumn{2}{|c|}{ Highly recommended } \\
\hline & $\square$ & Biographic or ecological classification system used (e.g. Holdridge Life Zone System) \\
\hline & $\square$ & $\begin{array}{l}\text { Additional climate variables (: e.g. maximum climatological water deficit, } \\
\text { seasonality in precipitation and in temperature.) }\end{array}$ \\
\hline & $\square$ & Dominant species \\
\hline & $\square$ & Stand structure (e.g. basal area, stand density-number of individuals per unit of area) \\
\hline & $\square$ & Phenology (e.g. deciduous, evergreen) \\
\hline & $\square$ & Landscape characteristics (slope, aspect) \\
\hline & $\square$ & Soil information (texture, depth) \\
\hline \multirow{11}{*}{$\begin{array}{l}\text { Sampling and laboratory } \\
\text { analysis }\end{array}$} & \multicolumn{2}{|c|}{ Mandatory } \\
\hline & $\square$ & Sampling criteria (e.g. diameter classes, species composition or guild, plot-based sampling) \\
\hline & $\square$ & Sample size \\
\hline & $\square$ & Range of values for diameter, height, wood specific gravity, tree components, etc. \\
\hline & $\square$ & Scientific and vernacular (if used) names \\
\hline & $\square$ & Methods used in the field or in the laboratory (e.g. method used to measure wood specific gravity) \\
\hline & \multicolumn{2}{|c|}{ Highly recommended } \\
\hline & $\square$ & Number of replicates \\
\hline & $\square$ & Instruments used in the field or in the laboratory (e.g. laser model for tree height measurement) \\
\hline & $\square$ & Precision of instruments used \\
\hline & $\square$ & Calculation procedures \\
\hline \multirow{12}{*}{$\begin{array}{l}\text { Model fitting, prediction } \\
\text { and uncertainty }\end{array}$} & \multicolumn{2}{|c|}{ Mandatory } \\
\hline & $\square$ & Functional form of the model(s) (e.g. power, non-linear, log-log) \\
\hline & $\square$ & Model mathematical formula, including form of the error term (multiplicative versus additive) \\
\hline & $\square$ & Data transformations (if any, e.g. log transformation) \\
\hline & $\square$ & Statistical parameters $\left(R^{2}, \mathrm{RSE}\right.$, mean bias, at a minimum) \\
\hline & $\square$ & Parameter values and confidence intervals of the parameters \\
\hline & $\square$ & Comparative statistics (e.g. $F$-value, AIC, BIC, Furnival index) \\
\hline & $\square$ & Software (and version) \\
\hline & \multicolumn{2}{|c|}{ Highly recommended } \\
\hline & $\square$ & Analysis scripts \\
\hline & $\square$ & Correlation matrix between parameters \\
\hline & $\square$ & Correlation between compartments in the case of SUR regressions \\
\hline \multirow[t]{5}{*}{ Meta data } & \multicolumn{2}{|c|}{ Highly recommended } \\
\hline & $\square$ & Purpose of the data \\
\hline & $\square$ & Dates of project \\
\hline & $\square$ & Data owner (contact information) \\
\hline & $\square$ & Storage and rights of use \\
\hline
\end{tabular}


or additional datasets. Several instruments are used to measure forest variables, and it is important to mention them so the reader can gauge their accuracy. For example, different biases can be associated with tree height measurement according to the instrument used (Hunter et al. 2013; Larjavaara and Muller-Landau 2013). The manuals developed by Anderson and Ingram (1993) and Picard et al. (2012) provide lengthy descriptions regarding laboratory techniques. In addition, forest mensuration manuals (e.g. Husch et al. 2002; Laar and Akça 2007) are sources of basic formulas and procedures for calculating volume, wood density, biomass expansion factors, and other variables, as well as procedures for dealing with outlier data, which should all be clearly described.

\subsection{Model fitting, prediction, and uncertainty}

Statistical parameters are needed to evaluate the robustness and the accuracy of any given model and to aid comparisons among them. The mathematical form of the models (e.g. power, log-transformed, and non-linear), distinguishing between additive and multiplicative error terms, and any transformations performed on the data (e.g. log and back transformation) must be clearly described with the associated formula, as they have important implications for interpreting and using allometric models (Zell et al. 2014).

Details about the software (name and version, at least) and processes used to fit the models are necessary to replicate model fits or run diagnostic tests. The best solution is to provide the scripts of the analyses as an appendix of the main document. Although the $R^{2}$ associated with the model is often provided, a description of other statistical parameters used to fully assess the goodness of the fit is advisable. Among them, the residual standard error (RSE) of the model and the mean bias should be provided for all models included in the document. Whenever multiple models are derived, we recommend that the statistical parameters used for model comparison and selection be described too (e.g. sum of squared estimated residuals (SSE), F-test, Akaike or Bayesian information criterion (AIC, BIC), Furnival index). Statistics on the data used for validation (sample size, relative average error, etc.) should also be indicated.

Finally, users are encouraged to present graphics illustrating the relationship between tree diameter versus tree height, diameter versus biomass, crown diameter versus biomass (if available), and predicted values versus observed values, at least in the appendices. Figures showing model fit must have complete descriptions of units used on the axes and in the figure captions.

\subsection{Metadata on raw data}

Raw data and its accompanying metadata help understand the scope and limitations of available datasets, calculate uncertainties, validate models, and construct new improved allometries. Properly documented volume data, for example, are very useful to develop biomass expansion factors, which are used by most countries to assess national forest biomass (FAO 2010). In contrast, poorly documented raw data or missing metadata preclude validation or further development equations based on expanded datasets.

Authors are encouraged to share their raw data to facilitate future efforts and to build collaborations within the scientific community. Data repositories such as Dryad (http://datadryad.org/), DataONE (http://www.dataone. org/), and others are now available for storing ecological and biological data. They offer the possibility of standardizing metadata and data formats and assigning a citable DOI number to the dataset.

\section{Conclusions}

The necessary criteria and information that scientists should use to develop allometric models and provide adequate information on them had not been considered before in a systematic manner. The recommendations we offer are meant to serve scientists and data users as a reference framework to improve biomass and volume allometric equation construction and reporting. These rules should be applied systematically and be part of a shared responsibility among authors, journal editors and reviewers, and users to improve reporting and use of allometric equations. Baldasso et al. (2012) and Picard et al. (2012) are good examples of how these guidelines can be incorporated into electronic formats and technical writing. We expect that the adoption of these guidelines will lead to a more complete, transparent, documented, and harmonized reporting of information on tree allometric equations worldwide, which will increase their value and robustness in predicting biomass and carbon.

Acknowledgments UN-REDD, FAO, and the SilvaCarbon Program provided funding for the "Regional Technical Workshop on Tree Volume and Biomass Allometric Equations in South and Central America", where ideas for this paper were first discussed. The BEF unit supported by the French National Research Agency (Agence Nationale de la Recherche, ANR) through the Laboratory of Excellence (Labex) ARBRE (ANR-12LABXARBRE-01). This work is part of the QLSPIMS project. MRM was supported by two "Investissement d'Avenir" grants managed by Agence Nationale de la Recherche (CEBA, ref. ANR-10-LABX-2501; TULIP, ref. ANR-10- LABX-0041) and by the CoForTip project (ANR12-EBID-0002). We also acknowledge the input of the 30 participants in this technical workshop.

Open Access This article is distributed under the terms of the Creative Commons Attribution License which permits any use, distribution, and reproduction in any medium, provided the original author(s) and the source are credited. 


\section{References}

Agrawal A, Nepstad D, Chhatre A (2011) Reducing emissions from deforestation and forest degradation. Annu Rev Env Resour 36: 373-396

Alvarez E, Duque A, Saldarriaga J, Cabrera K, de las Salas G, del Valle I, Lema A, Moreno F, Orrego S, Rodríguez L (2012) Tree aboveground biomass allometries for carbon stocks estimation in the natural forests of Colombia. For Ecol Manage 267:297-308. doi: 10.1016/j.foreco.2011.12.013

Anderson JM, Ingram JSI (1993) Tropical soil biology and fertility: a handbook of methods. TSBF, Wallingford

Bailey RG (1989) Explanatory supplement to ecoregions map of the continents. Environ Conserv 16:307-309

Baldasso M, Birigazzi L, Trotta C, Henry M (2012) Tutorial for tree allometric equation database development. Food and Agriculture Organization of the United Nations (FAO), Università degli Studi della Tuscia, Department for Innovation in Biological, Agro-Food and Forest System (UNITUS-DIBAF), Centre de coopération internationale en recherche agronomique pour le développement (CIRAD). Rome, IT

Bombelli A, Avitabile V, Belelli Marchesini L, Balzter H, Bernoux M, Hall R, Henry M, Law BE, Manlay R, Marklund LG, Shimabukuro YE (2009) Biomass - assessment of the status of the development of the standards for the terrestrial essential climate variables. Food and Agriculture Organization - Global Terrestrial Observation System. GTOS, Rome

Brown S (1997) Estimating biomass and biomass change of tropical forests: a primer. FAO Forestry Paper-134. Food and Agriculture Organization of the United Nations, Roma

Chave J, Andalo C, Brown S, Cairns MA, Chambers JQ, Eamus D, Fölster H, Fromard F, Higuchi N, Kira T, Lescure J-P, Nelson B, Ogawa H, Puig H, Riéra B, Yamakura T (2005) Tree allometry and improved estimation of carbon stocks and balance in tropical forests. Oecologia 145:87-99

Chave J, Réjou-Méchain M, Búrquez A, Chidumayo E, Colgan MS, Delitti WBC, Duque A, Eid T, Fearnside PM, Goodman MHRC, Martínez-Yrízar A, Mugasha WA, Muller-Landau HC, Mencuccini M, Nelson BW, Ngomanda A, Nogueira EM, Ortiz-Malavassi E, Pélissier R, Ploton P, Ryan CM, Saldarriaga JG, Vieilledent G (2014) Improved pantropical allometric models to estimate the above ground biomass of tropical forests. Glob Change Biol. doi: $10.1111 /$ gcb. 12629

Chojnacky DC, Heath LS, Jenkins JC (2014) Updated generalized biomass equations for North American tree species. Forestry 87:129 151

FAO (2001) Global ecological zoning for the global forest resources assessment 2000. The Forest Resources Assessment Programme. Rome, IT

FAO (2010) Global forest resources assessment 2010. The Food and Agriculture Organization of the United Nations, Rome

Feldpausch T, Banin L, Phillips O, Baker T, Lewis S, Quesada C, AffumBaffoe K, Arets EJ, Berry N, Bird M, Brondizio E, de Camargo P, Chave J, Djagbletey G, Domingues T, Drescher M, Fearnside P, França M, Fyllas N, Lopez-Gonzalez G, Hladik A, Higuchi N, Hunter M, Iida Y, Abu Silam K, Kassim A, Keller M, Kemp J, King D, Lovett J, Marimon B, Marimon-Junior B, Lenza E, Marshall A, Metcalfe D, Mitchard E, Moran E, Nelson B, Nilus R, Nogueira E, Palace M, Patiño S, Peh K, Raventos M, Reitsma J, Saiz G, Schrodt F, Sonké B, Taedoumg H, Tan S, White L, Wöll H, Lloyd J (2010) Height-diameter allometry of tropical forest trees. Biogeosci Discuss 7:7727-7793. doi:10.5194/bgd-7-7727-2010

Henry M, Picard N, Manlay R, Valentini R, Bernoux M, SaintAndré L (2011) Estimating tree biomass of sub-Saharan African forests: a review of available allometric equations. Silva Fenn Monogr 45:1-94
Henry M, Bombelli A, Trotta C, Alessandrini A, Birigazzi L, Sola G, Vieilledent G, Santenoise P, Longuetaud F, Valentini R, Picard N, Saint-André L (2013) GlobAllomeTree: international platform for tree allometric equations to support volume, biomass and carbon assessment. iForest Biogeosci Forest 6:326-330. doi:10.3832/ ifor0901-006

Holdridge LR (1967) Life zone ecology. Revised edition. Tropical Science Center, San José

Hunter MO, Keller M, Vitoria D, Morton DC (2013) Tree height and tropical forest biomass estimation. Biogeosci Discuss 10:1049110529. doi:10.5194/bgd-10-10491-2013

Husch B, Beers TW, Kershaw JA (2002) Forest mensuration, 4th edn. Wiley, Hoboken

IPCC (2003) Good practice guidance for land use, land-use change and forestry. IPCC National Greenhouse Gas Inventories Programme, Kanagawa

IPCC (2006) 2006 IPCC guidelines for national greenhouse gas inventories. Prepared by the National Greenhouse Gas Inventories Programme. Eggleston HS, Buendia L, Miwa K, Ngara T, Tanabe K (eds) IGES, Hayama

Jenkins JC, Chojnacky DC, Heath LS, Birdsey RA (2003) Comprehensive database of diameter-based biomass regressions for North American tree species. USDA Forest service, Delaware

Laar AV, Akça A (2007) Forest mensuration, vol 13. Managing forest ecosystems, vol 13, 2nd edn. Springer, Dordrecht

Larjavaara M, Muller-Landau HC (2013) Measuring tree height: a quantitative comparison of two common field methods in a moist tropical forest. Method Ecol Evol 4:793-801. doi:10.1111/2041-210x. 12071

Ngomanda A, Engone Obiang NL, Lebamba J, Moundounga Mavouroulou Q, Gomat H, Mankou GS, Loumeto J, Midoko Iponga D, Kossi Ditsouga F, Zinga Koumba R, Botsika Bobé KH, Mikala Okouyi C, Nyangadouma R, Lépengué N, Mbatchi B, Picard N (2014) Site-specific versus pantropical allometric equations: which option to estimate the biomass of a moist central African forest? For Ecol Manage 312:1-9. doi:10.1016/j.foreco. 2013.10.029

Olson DM, Dinerstein E, Wikramanayake ED, Burgess ND, Powell VN, Underwood EC, D'Amico JA, Itoua I, Strand HE, Morrison JC, Loucks CJ, Allnutt TF, Ricketts TH, Kura Y, Lamoreux JF, Wettengel WW, Hedao P, Kassem KR (2001) Terrestrial ecoregions of the world: a new map of life on earth. Bioscience 51:933-938

Picard N, Saint André L, Henry M (2012) Manual for building tree allometric equations: from the field to the prediction. Food and Agriculture Organization of the United Nations, Centre de Coopération Internationale en Recherche Agronomique, Rome

Ponce-Hernandez R (2004) Assessing carbon stocks and modelling winwin scenarios of carbon sequestration through land-use changes. Food and Agriculture Organization of the United Nations, Rome

Pretzsch H, Biber P, Durský J, von Gadow K, Hasenauer H, Kändler G, Kenk G, Kublin E, Nagel J, Pukkala T, Skovsgaard JP, Sodtke R, Sterba H (2002) Recommendations for standardized documentation and further development of forest growth simulators. Forstw $\mathrm{Cbl}$ 121:138-151. doi:10.1046/j.1439-0337.2002.00138.x

Ribeiro S, Fehrmann L, Soares C, Jacovine L, Kleinn C, de Oliveira GR (2011) Above- and belowground biomass in a Brazilian Cerrado. For Ecol Manage 262:491-499. doi:10.1016/j.foreco.2011.04.017

Udvardy MDF (1975) A classification of the biogeographical provinces of the world. IUCN, Morges, $\mathrm{p} 48$

Vogt KA, Vogt DJ, Bloomfield J (1998) Analysis of some direct and indirect methods for estimating root biomass and production of forests at an ecosystem level. Plant Soil 200:71-89

Zell J, Bösch B, Kändler G (2014) Estimating above-ground biomass of trees: comparing Bayesian calibration with regression technique. Eur J For Res. doi:10.1007/s10342-014-0793-7 